\title{
PENGARUH JIWA KEWIRAUSAHAAN TERHADAP KEBERHASILAN USAHA CAFE DI KOTA PALEMBANG
}

\author{
Dian Utari' ${ }^{1}$, Muhammad Yusrik ${ }^{2}$ \\ Sekolah Tinggi Ilmu Ekonomi Mulia Darma Pratama Palembang \\ Email : $\underline{\text { utaridian767@gmail.com }}{ }^{1}$, yusri0141@gmail.com²
}

\begin{abstract}
ABSTRAK
Keberhasilan usaha biasanya dipengaruhi oleh banyak faktor baik dari lingkungan internal maupun lingkungan eksternal perusahaan. Faktor dari lingkungan internal biasanya berasal dari dalam lingkungan perusahaan itu sendiri yang cenderung dapat di kontrol. Salah satu faktor internal dari keberhasilan usaha adalah faktor semangat jiwa kewirausahaan. Penelitian ini akan membahas "Pengaruh jiwa kewirausahaan terhadap keberhasilan usaha café di Kota Palembang". Rumusan masalah pada penelitian ini adalah 1. Bagaimanakah pengaruh Jiwa kewirausahaan terhadap keberhasilan usaha Cafe di Kota Palembang secara parsial? 2. Bagaimanakah pengaruh Jiwa kewirausahaan terhadap keberhasilan usaha Cafe di Kota Palembang secara simultan?. Tujuan dari penelitian ini adalah 1. Untuk mengetahui pengaruh Jiwa kewirausahaan terhadap keberhasilan usaha Cafe di Kota Palembang secara parsial. 2. Untuk mengetahui pengaruh Jiwa kewirausahaan terhadap keberhasilan Usaha Cafe di Kota Palembang secara parsial. Objek dalam penelitian ini adalah 33 usaha Cafe di kota Palembang yang berhasil dikumpulkan oleh peneliti. Penelitian ini mengunakan metode analisis kuantitatif. Adapun jumlah sempel yang terkumpul sebanyak 33 responden dan teknik sampel yang dipakai dengan cara purposive sampling. Dari hasil penelitian dan interprestasi data yang telah dianalisis mengunakan analisis regresi berganda menunjukan bahwa 67,3\% jiwa kewirausahaan yang terdiri dari variabel percaya diri, berorientasi pada tugas dan hasil, berani mengambil resiko, kepemimpinan, keorisinilan dan berorientasi pada masa depan berpengaruh terhadap keberhasilan usaha Cafe di kota Palembang dan secara simultan mempunyai pengaruh yang positif signifikan terhadap keberhasilan usaha dimana $\mathrm{F}_{\text {hitung }}$ lebih besar dari $\mathrm{F}_{\text {tabel }}: 8,929>2,42$ pada taraf nyata 5\% dan nilai signifikan sebesar 0,000 . Penelitian ini juga menunjukan bahwa dimensi yang paling dominan mempengaruhi tingkat keberhasilan usaha Cafe di kota Palembang adalah dimensi percaya diri dengan koefisien regresi sebesar 0,436. Untuk meningkatkan semangat jiwa kewirausahaan yang mana akan berpengaruh terhadap keberhasilan usaha Cafe di kota Palembang perlu menanamkan kembali semangat jiwa kewirausahaan. Hal ini dilakukan agar para penggiat usaha Cafe benar-benar menjadi seorang wirausaha atau pengusaha sejati.
\end{abstract}

Kata kunci : Jiwa Kewirausahaan dan Keberhasilan Usaha 


\begin{abstract}
Success business is usually influenced by many factors, both from the internal and external environment of the company. Factors from the internal environment usually come from within the company's own environment which tends to be controlled. One of the internal factors of business success is the entrepreneurial spirit factor. This study will discuss "The influence of the entrepreneurial spirit on the success of a cafe business in Palembang City". The formulation of the problem in this study is 1 . the influence of the entrepreneurial spirit on the success of the Cafe business in Palembang City partially? 2. The influence of the Entrepreneurial Spirit on the success of the Cafe business in Palembang City simultaneously?. The purposes of this study are 1. To determine the influence of the entrepreneurial spirit on the success of the cafe business in Palembang City partially. 2. To find out the influence of Entrepreneurial Spirit on the success of Cafe Business in Palembang City partially. The object of research in this study were 33 cafe businesses in the city of Palembang which were collected by researchers. This study uses quantitative analysis methods. The number of samples collected was 33 respondents and the sample technique used was purposive sampling. From the results of research and interpretation of data that has been analyzed using multiple analysis shows that $67.3 \%$ entrepreneurial spirit which consists of variables of confidence, tasks and results, leadership, leadership, and future development affect the success of the cafe business in the city of Palembang and overall. Simultaneous has a significant positive effect on business success where Fcount is greater than Ftable: 8,929 > 2,42 at 5\% significance level and significant value is 0.000. This study also shows that the most dominant dimension influencing the success rate of Cafe business in Palembang is the self-confidence dimension with a regression coefficient of 0.436 . To increase the entrepreneurial spirit which will affect the success of the cafe business in the city of Palembang, it is necessary to instill an entrepreneurial spirit. This is done so that the cafe business activists really become entrepreneurs or true entrepreneurs.
\end{abstract}

\title{
Keywords: Entrepreneurial Spirit and Business Success
}

\section{PENDAHLUAN}

Di Indonesia bisnis Cafe makin menjanjikan, mengingat ngumpul di Cafe sudah jadi gaya hidup masyarakat kita dari usia belia sampai usia matang. Melihat hal ini Reed Panorama Exhibilitions (RFE) berencana mengelar Cafe Braserie Indonesia (CBI) yang di dukung berbagai Asosiasi. CBI diharapkan bisa menjadi wadah bagi para pelaku usaha di sektor Cafe untuk dapat bertukar informasi serta membangun jaringan antara pelaku usaha. CBI juga diharapkan mampu mendorong munculnya para pengusaha Cafe dan investor di Indonesia (majalah Sedap, 2016:103).

Cafe biasanya digunakan untuk berkumpul atau bersosialisasi, mengisi waktu liburan, hingga tidak jarang digunakan untuk pertemuan dan menjamu rekan bisnis oleh para eksekutif yang bersifat informal. Cafe juga di gandrungi oleh berbagai kalangan baik remaja, dewasa bahkan Cafe sering dijadikan tempat ngumpul Ibu-ibu sosialita untuk acara arisan, reuni, atau sekedar temu kangen dengan teman lama.

Istilah Cafe menurut wikipedia yaitu berasal dari bahasa Perancis yang secara harpiah artinya (minuman) Kopi, kemudian menjadi tempat untuk minum-minuman yang bukan hanya kopi, tetapi juga minuman lainya. Cafe biasanya tidak menyediakan menu makanan utama namun hanya menyediakan minuman dan makanan ringan sebagai menu hidangan dan juga menyediakan live music sebagai hiburan. Menurut Kanal Informasi, Cafe adalah Restouran kecil yang melayani atau menjual makanan ringan dan minuman, Cafe biasanya digunakan orang untuk rileks (Dictionery of inglis language and culture).

Banyaknya Cafe yang ada di Indonesia membuat daya saing antara pengiat usaha semakin 
ketat, oleh karena itu perlu adanya identitas Cafe yang berbeda dengan Cafe lainya baik dari segi bentuk minuman dan makanan, rasa, maupun konsep. Dengan demikian barulah Cafe tersebut dapat di ingat oleh masyarakat karena perbedaanya yang unik dan hal ini membuat usaha Cafe maju dan berkembang, sehingga keberhasilan usaha Cafe dapat tercapai sesuai dengan tujuan yang telah di rancang sebelumnya.

Keberhasilan usaha dapat $d$ inilai

melalui beberapa indikator atau beberapa pendekatan yaitu pendekatan pencapaian tujuan, pendekatan Sistem, pendekatan Konstituensi Strategis, dan pendekatan nilai-nilai bersaing (Suranti, 2006:46). Keberhasilan usaha juga dapat di pengaruhi oleh berbagai faktor, diantaranya adalah jiwa kewirausahaan. Seperti yang di kemukakan oleh Harris (2000:19) yang dikutip Suryana (2008:5), "wirausaha yang sukses pada umumnya adalah mereka yang memiliki kopetensi, yaitu memiliki ilmu pengetahuan, keterampilan, dan kualitas individu yang meliputi sikap, motivasi, nilai-nilai pribadi, serta tingkah laku yang diperlukan untuk melaksanakan pekerjaan atau kegiatan."

Alma (2014 : 53), mengemukakan bahwa keberhasilan usaha juga bisa di lihat dengan memiliki sifat-sifat seorang wirausaha (karakteristik jiwa kewirausahaan) yaitu percaya diri, berorientasi pada tugas dan hasil, pengambilan resiko, kepemimpinan, keorisnilan, berorientasi pada masa depan. Menurut Suparyanto (2012:24), jiwa kewirausahaan bisa dapat dimiliki seseorang sebagai bakat pembawaan sejak kelahiranya. Jiwa kewirausaahaan juga dapat di bentuk melalui proses Pendidikan dan pengalaman. Pengertian kewirausahaan menurut Hisrich (1995:6), yang di kutif Alma (2014: 23), Kewirausahaan atau Enterprenuer adalah proses menciptakan sesuatu yang berbeda dengan mengambil seluruh waktu dan tenaganya disertai dengan menanggung resiko keuangan, kejiwaan, sosial dan menerima balas jasa dalam bentuk uang dan kepuasan pribadinya.

Usaha Cafe kini tengah berkembang di Indonesia, karna kebiasaan masyarakat Indonesia yang suka nongkrong di Cafe sudah jadi gaya hidup, maka hal ini berimbas pada menjamurnya usaha Cafe di kota-kota besar di Indonesia. Di antaranyas adalah kota Palembang, dengan jumlah penduduk yang semakin bertambah, di sertai dengan banyaknya penyelengaraan kegiatan Internasional membuat Palembang memiliki daya tarik tersendiri bagi para pelaku usaha Cafe.

Banyaknya Cafe yang ada di kota Palembang membuat daya saing antar pegiat usaha semakin sempit, oleh karena itu perlu adanya identitas Cafe yang berbeda dengan Cafe lainya. Seperti yang dikuti dalam majalah Bisnis "bagi para pembisnis kuliner, berbisnis bukan hanya sekedar tempat menjual minuman atau makanan, tetapi bisnis kuliner yang dibangun hanya dapat bersaing ketika pemilik bersenjatakan konsep unik, kreatif dan inovatif'(Majalah bisinis 2014:48). Oleh karena itu, dengan Jiwa kewirausahaan yang di dalamnya ada indikator Keorisinilan yang terdapat dimensi kreativitas dan inovasi maka, akan banyak bermunculan para pengusaha-pengusaha muda yang tentu tidak memperkaya diri sendiri tetapi juga turut membantu perekonomian masyarakat dengan cara menyerap tenaga kerja yang tidak bisa diatasi sepenuhnya oleh pemerintah yang memiliki kemampuan terbatas.

Penelitian yang dilakukan oleh Farah Balqish (2015) dengan judul "pengaruh jiwa kewirausahaan terhadap keberhasilan usaha Distro di kota Bandung", mengidentifikasi bahwa "secara Simultan jiwa kewirausahaan berpengaruh signifikan sebesar 94\% terhadap keberhasilan usaha sedangkan $6 \%$ dipengaruhi oleh faktor lain yang tidak di teliti dalam penelitianya".Dari pelitian yang dilakukan oleh Farah Balqish (2015) penulis ingin meneliti ulang, apakah dengan objek yang berbeda, tempat penelitian berbeda, waktu penelitian yang berbeda dan teknik sempling yang berbeda akan memperoleh hasil yang sama dengan penelitan yang dilakukan oleh Farah Balqish (2015).

Berdasarkan uraian diatas, maka judul yang
dipilih adalah
"PENGARUH
KEWIRAUSAHAAN TERHADAP KEBERHASILAN USAHA CAFE DI KOTA PALEMBANG". 


\section{METODOLOGI PENELITIAN Kewirausahaan}

Menurut Peters (1995:10), yang dikutip Alma (2014 :33), defenisi yang paling baik dari wirausaha ialah : entrepreneurship is the process of creating something different with value by devoting the necessary time and effort, assuming the accompaying financial, psychic, and social risks, and receiving the resulting rewords of monetary and personal satisfaction and independence. Artinya Kewirausahaan adalah proses menciptakan sesuatu yang lain dengan mengunakan waktu dan kegiatan disertai modal dan resikoserta merima balas jasa dan kepuasan serta kebebasan pribadi. Menurut Suryana (2011:2), kewirausahaan (enterprenurship) adalah kemampuan kreatif dan inovatif yang dijadikan dasar, kiat, dan sumber daya untuk mencari peluang menuju sukses.

\section{Jiwa kewirausahaan}

Suryana (2011 :2), Jiwa kewirausahaan adalah sikap atau prilaku orang-orang yang memiliki kepribadian kreatif dan inovatif dengan memiliki ciri-ciri tertentu.Suryana (2011:24), Ciri-ciri umum kewirausahaan dapat di lihat dari berbagai aspek kepribadian, seperti jiwa, watak, sikap, dan prilaku seseorang yaitu percaya diri, berorientasi pada hasil, berani mengambil resiko, kepemimpinan, keorisinilan, dan berorientasi pada masa depan.

Menurut Alma (2014: 52-57), untuk menjadi wirausahawan, seseorang harus memiliki ciri-ciri atau karakteristik (jiwa kewirausahaan), sebagai berikut:

Tabel 1

Ciri-ciri atau karakteristik (Jiwa Kewirausahaan)

\begin{tabular}{|r|l|l|}
\hline NO & \multicolumn{1}{|c|}{ CIRI-CIRI } & \multicolumn{1}{c|}{ WATAK } \\
\hline 1. & Percaya diri & $\begin{array}{l}\text { Kepercayaan (keteguhan) } \\
\text { Ketidaktergantungan } \\
\text { Kepribadian mantap } \\
\text { Optimisme }\end{array}$ \\
\hline 2. & $\begin{array}{l}\text { Berorientasikan Pada } \\
\text { tugas dan hasil }\end{array}$ & $\begin{array}{l}\text { Kebutuhan atau haus akan } \\
\text { prestasi } \\
\text { Berorientasi laba atau hasil } \\
\text { Tekun dan tabah } \\
\text { Tekad kerja keras, motivasi } \\
\text { Energik } \\
\text { Penuh inisiatif }\end{array}$ \\
\hline 3. & Pengambilan resiko & $\begin{array}{l}\text { Mampu mengambil resiko } \\
\text { Suka pada tantangan }\end{array}$ \\
\hline 4. & Kepemimpinan & $\begin{array}{l}\text { Mampu memimpin } \\
\text { Dapat bergaul dengan orang lain } \\
\text { Menanggapi saran dan kritik }\end{array}$ \\
\hline 5. & Keorisinilan & $\begin{array}{l}\text { Inovatif (pembaharu) } \\
\text { Kreatif } \\
\text { Fleksibel } \\
\text { Banyak sumber } \\
\text { Serba bisa } \\
\text { Mengetahui banyak }\end{array}$ \\
\hline 6. & $\begin{array}{l}\text { Berorientasi } \\
\text { depan }\end{array}$ & $\begin{array}{l}\text { Pandangan kedepan } \\
\text { Perseptif }\end{array}$ \\
\hline
\end{tabular}

Sumber: Buchari Alma. Kewirausahaan.Edisi Revisi. Hal. 52-53 


\section{Percaya diri}

Menurut Wijandi (1988:33), yang di yang dikutip Suryana (2011:39), Kepercayaan Diri merupakan suatu panduan sikap dan keyakinan seseorang dalam menghadapi tugas atau pekerjaan. Seserang yang memiliki kepercayaan diri cendrung memiliki keyakinan akan kemampuanya untuk mencapai keberhasilan (Zimmerer, 1996:7) yang dikutip Suryana (2011:39).

\section{Berorientasi Pada Tugas dan Hasil}

Seseorang yang selalu mengutamakan dan hasil adalah orang yang selalu mengutamakan nilai-nilai motif berprestasi, berorientasi pada laba, ketekunan dan ketabahan tekad kerja keras mempunyai dorongan yang kuat, energik dan berinisiatif (Suryana, 2011:40).

\section{Berani Pengambilan Resiko}

Seseorang yang berani mengambil resiko adalah orang yang selalu ingin jadi pemenang dan memenangkan dengan cara yang baik (Wirasasmita,1994:2) dikutip oleh Suryana (2011:40).

\section{Kepemimpinan}

Menurut Terry yang dikutip Alma ledership is the activity of influencing people to strive willingly for graup objectives. Artinya kepemimpinan adalah aktivitas orang untuk berusha secara sukarela untuk tujuan grup.

\section{Keorisinilan}

Keorisiilan adalah unsur-unsur nilai kreatif dan fleksibilitas seseorang (Suryana, 2011:42). Yang dimaksud orisinil disini ialah tidak hanya mengekor pada orang lain, tetapi memiliki pendapat sendiri, ada ide yang orisinil. Ada kemampuan untuk melaksanakan sesuatu. Orisinil tidak berarti baru sama sekali, tetap produk tersebut mencerminkan hasil kombinasi baru atau reintergrasi dari komponen-komponen yang sudah ada, sehingga melahirkan sesuatu yang baru

\section{Berorientasi Pada Masa Depan}

Orang yang berorientasi kemasa depan adalah Seorang wirausaha yang memiliki perspektif, mempunyai visi ke depan, apa yang hendak ia lakukan, apa yang hendak ia lakukan,apa yang ingin ia capai, sebab sebuah usaha bukan didirikan untuk sementara, tetapi untuk selamanya. Oleh sebab itu, faktor konstinuitasnya harus dijaga dan pandangan harus ditunjukan jauh kedepan. Untuk menghadapi pandangan jauh ke depan, agar jelas langkah-langkah yang akan dilaksanakan (Alma,2014:54).

\section{Keberhasilan usaha}

Menurut Mudzakar (1998 :73), Keberhasilan usaha adalah suatu keadaan yang menggambarkan lebih dari pada lainya yang sederajat atau sekelasnya. Suatu usaha dikatakan berhasil apabila memiliki suatu kelebihan dibandingkan dengan periode sebelumnya atau dengan perusahaan sekelasnya. Dalam pengertian umum, keberhasilan usaha menunjukan suatu keadaan yang lebih baik atau unggul dari pada masa sebelumnya.

Keberhasilan usaha dapat dinilai melalui beberapa indikotor atau empat pendekatan pendekatan pencapaian tujuan, pendekatan Sistem, pendekatan Konstituensi Strategis, dan pendekatan nilai-nilai bersaing (Suranti, 2006:46).

\section{Hipotesis}

Ho: $\beta_{123456}=0$ : diduga secara parsial tidak terdapat pengaruh yang positif dan signifikan dari Jiwa Kewirausahaan (X) yang terdiri dari variabel Percaya Diri $\left(X_{1}\right)$, berorientasi pada tugas dan hasil $\left(X_{2}\right)$, keberanian mengambil resiko $\left(X_{3}\right)$, kepemimpinan $\left(X_{4}\right)$,keorisinilan $\left(X_{5}\right)$, berorientasi pada masa depan $\left(X_{6}\right)$ terhadap keberhasilan usaha Cafe di kota Palembang.

Ha: $\beta_{123456}=0$ : diduga secara parsial terdapat pengaruh yang positif dan signifikan dari Jiwa kewirausahaan (X) yang terdiri dari variabel Percaya Diri $\left(X_{1}\right)$, berorientasi pada tugas dan hasil $\left(X_{2}\right)$, keberanian mengambil 
resiko $\left(X_{3}\right)$, kepemimpinan $\left(X_{4}\right)$, keorisinilan $\left(X_{5}\right)$, berorientasi pada masa depan $\left(X_{6}\right)$ terhadap keberhasilan usaha Cafe di kota Palembang.

Ho: $\beta_{123456}=0$ : diduga secara simultan tidak terdapat pengaruh yang positif dan signifikan dari variabel bebas jiwa kewirausahaan $(\mathrm{X})$ yang terdiri dari Percaya Diri $\left(X_{1}\right)$, berorientasi pada tugas dan hasil $\left(X_{2}\right)$, keberanian mengambil resiko $\left(X_{3}\right)$, kepemimpinan $\quad\left(X_{4}\right), \quad$ keorisinilan $\left(X_{5}\right)$, berorientasi pada masa depan $\left(X_{6}\right)$ terhadap Keberhasilan Usaha $(\mathrm{Y})$.

Ho: $\beta_{123456}=0$ : diduga secara simultan terdapat pengaruh yang positif dan signifikan dari variabel bebas Jiwa kewirausahaan $(\mathrm{X})$ yang terdiri dari Percaya Diri $\left(X_{1}\right)$, berorientasi pada tugas dan hasil $\left(X_{2}\right)$, keberanian mengambil resiko $\left(X_{3}\right)$, kepemimpinan $\quad\left(X_{4}\right), \quad$ keorisinilan $\left(X_{5}\right)$, berorientasi pada masa depan $\left(X_{6}\right)$ terhadap Keberhasilan Usaha $(Y)$.

\section{Objek penelitian}

Objek dalam penelitian ini adalah pengusaha atau penggiat usaha Cafe yang ada di kota Palembang.

\section{Populasi}

Populasi dalam penelitian ini adalah semua wirausahawan atau penggiat usaha yang memiliki usaha Cafe yang ada di kota Palembang.

\section{Sampel penelitian}

Sampel yang berhasil dikumpulkan oleh penulis dalam penelitian ini adalah 33 sampel atau responden.
Teknik Sempling yang digunakan adalah Purposive Sempling (Notoatmojo, 2010:47), yaitu pengambilan sempel yang berdasarkan atas suatu pertimbangan tertentu seperti sifat-sifat populasi atau ciri-ciri yang suda diketahui sebelumnya.

\section{Metode penelitian}

Dalam Metode ini mengunakan metode Asosiatif yaitu metode yang menggambarkan, menjelaskan, memaparkan, dan menguraikan suatu hubungan tertentu yang ada kaitanya dengan permasalahan yang akan dibahas.

\section{Metode Analisis Data}

Metode Analisis data yang digunakan dalam penelitian ini adalah metode analisis kuantitatif yang artinya analisis yang berlandaskan pada filsafat positivisme, digunakan untuk meneliti pada populasi dan sampel tertentu, pengumpulan data menggunakan instrumen penelitian, analisis data bersifat kuantitatif atau statistik, dengan tujuan untuk menguji hipotesis yang telah ditetapkan (Sugiono, 2010:13). Sebelum melakukan pengujian hipotesis dilakukan langkah-langkah sebebagai berikut:

1. Pengujian Alat Pengumpulan Data

a. Uji Validitas

b. Uji Realibilitas

c. Uji Normalitas

d. Uji Homogenitas

e. Uji t

f. $\mathrm{R}^{2}$ atau Koefisien determinasi

g. Uji F

\section{HASIL DAN PEMBAHASAN}

Tabel 2

Hasil Uji Validitas

\begin{tabular}{|l|c|c|c|c|}
\hline \multicolumn{1}{|c|}{ VARIABEL } & ITEM & $\boldsymbol{R}_{\text {hitung }}$ & $\boldsymbol{t}_{\text {tabel }}$ & Keterangan \\
\hline Percaya Diri (X1) & X1.1 & 0,703 & 0,355 & Valid \\
& X1.2 & O,818 & 0,355 & Valid \\
& X1.3 & 0,679 & 0,355 & Valid \\
& X1.4 & 0,822 & 0,355 & Valid \\
\hline Berorientasi Pada Tugas dan & X2.1 & 0,694 & 0,355 & Valid \\
Hasil (X2) & X2.2 & 0,721 & 0,355 & Valid \\
\hline
\end{tabular}




\begin{tabular}{|l|c|c|c|c|}
\hline & X2.3 & 0,734 & 0,355 & Valid \\
& X2.4 & 0,849 & 0,355 & Valid \\
\hline Keberanian Mengambil Resiko & X3.1 & 0,664 & 0,355 & Valid \\
& X3.2 & 0,867 & 0,355 & Valid \\
& X3.3 & 0,728 & 0,355 & Valid \\
& X3.4 & 0,764 & 0,355 & Valid \\
\hline Kepemimpinan (x4) & X4.1 & 0,794 & 0,355 & Valid \\
& X4.2 & 0,699 & 0,355 & Valid \\
& X4.3 & 0,680 & 0,355 & Valid \\
& X4.4 & 0,585 & 0,355 & Valid \\
\hline Keorisinilan (x5) & X5.1 & 0,792 & 0,355 & Valid \\
& X5.2 & 0,710 & 0,355 & Valid \\
& X5.3 & 0,779 & 0,355 & Valid \\
& X5.4 & 0,735 & 0,355 & Valid \\
\hline Berorientasi Pada Masa Depan & X6.1 & 0,668 & 0,355 & Valid \\
(X6) & X6.2 & 0,739 & 0,355 & Valid \\
& X6.3 & 0,722 & 0,355 & Valid \\
& X6.4 & 0,837 & 0,355 & Valid \\
\hline Keberhasilan usaha (Y) & Y1 & 0,780 & 0,355 & Valid \\
& Y2 & 0,811 & 0,355 & Valid \\
& Y3 & 0,846 & 0,355 & Valid \\
& Y4 & 0,841 & 0,355 & Valid \\
\hline
\end{tabular}

Sumber : data primer yang diolah IBM SPSS Statistics Ver. 23

Tabel 3

Hasil Uji Realibilitas

\begin{tabular}{|l|c|c|}
\hline \multicolumn{1}{|c|}{ Variabel } & $\begin{array}{c}\text { Nilai Cronbach } \\
\text { Alpha }\end{array}$ & Keterangan \\
\hline Percaya Diri (X1) & 0,778 & Realiabel \\
\hline Berorientasi Pada Tugas dan Hasil (X2) & 0,796 & Realiabel \\
\hline Keberanian Mengambil Resiko (X3) & 0,802 & Realiabel \\
\hline Kepemimpinan (x4) & 0,759 & Realiabel \\
\hline Keorisinilan (x5) & 0,782 & Realiabel \\
\hline Berorientasi Pada Masa Depan (X6) & 0,795 & Realiabel \\
\hline Keberhasilan usaha (Y) & 0,813 & Realiabel \\
\hline
\end{tabular}

Sumber : data primer yang diolah IBM SPSS Statistics Ver. 23

Tabel 4

Hasil Uji Normalitas 


\begin{tabular}{|ll|r|}
\hline Normal Parameters ${ }^{\mathrm{a}, \mathrm{b}}$ & Mean & 33 \\
& Std. & .0000000 \\
& Deviation & 1.28204552 \\
& & .118 \\
Most Extreme Differences Absolute & .118 \\
& Positive & -.091 \\
& Negative & .118 \\
Test Statistic & $.200^{\mathrm{c}, \mathrm{d}}$ \\
Asymp. Sig. (2-tailed) & & \\
\multicolumn{2}{|l|}{ Sumber : Data primer yang diolah IBM SPSS Statisctic Ver 23 }
\end{tabular}

Gambar 1

Grafik Kolmogorov Smirnov

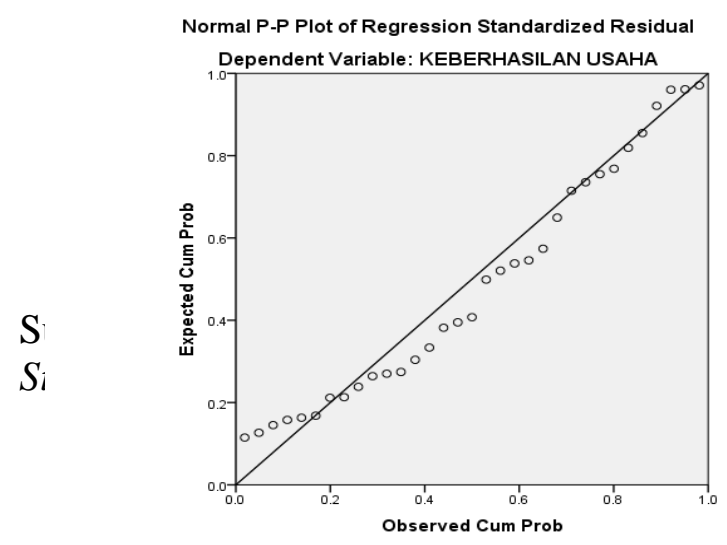

Tabel 5

Uji Homogenitas

\begin{tabular}{|c|c|c|}
\hline Variabel & Sig. & Keterangan \\
\hline Percaya diri $\mathrm{X}_{1}$ & 0,169 & Homogen \\
\hline Beroroentasi Pada Tugas Dan Hasil $\mathrm{X}_{2}$ & 0,321 & Homogen \\
\hline Berani mengambil Resiko $\mathrm{X}_{3}$ & 0,598 & Homogen \\
\hline Kepemimpinan $\mathrm{X}_{4}$ & 0,387 & Homogen \\
\hline Keorisinilan $\mathrm{X}_{5}$ & 0,304 & Homogen \\
\hline Berorientasi Pada Masa Depan $\mathrm{X}_{6}$ & 0,014 & Homogen \\
\hline
\end{tabular}

Sumber : data primer yang diolah IBM SPSS Statistics Ver. 23

Tabel 6

Coefficients $^{\mathbf{a}}$ 


\begin{tabular}{|c|c|c|c|c|c|c|}
\hline \multirow{2}{*}{\multicolumn{2}{|c|}{ Model }} & \multicolumn{2}{|c|}{$\begin{array}{l}\text { Unstandardized } \\
\text { Coefficients } \\
\end{array}$} & \multirow{2}{*}{\begin{tabular}{|c|}
$\begin{array}{c}\text { Standardized } \\
\text { Coefficients }\end{array}$ \\
Beta \\
\end{tabular}} & \multirow[b]{2}{*}{$\mathrm{t}$} & \multirow[b]{2}{*}{ Sig. } \\
\hline & & B & Std. Error & & & \\
\hline \multirow[t]{7}{*}{1} & (Constant) & -6.829 & 3.689 & & -1.851 & .076 \\
\hline & PERCAYA DIRI & .436 & .163 & .397 & 2.682 & .013 \\
\hline & $\begin{array}{l}\text { BERORIENTASI } \\
\text { PADA HASIL }\end{array}$ & .119 & .225 & .086 & .530 & \\
\hline & $\begin{array}{l}\text { BERANI MENGABIL } \\
\text { RESIKO }\end{array}$ & -.146 & .243 & -.102 & -.602 & \\
\hline & KEPEMIMPINAN & .409 & .171 & .358 & 2.391 & .024 \\
\hline & KEORISINILAN & .241 & .218 & .191 & 1.105 & .279 \\
\hline & $\begin{array}{l}\text { BERORIENTASI } \\
\text { PADA MASA } \\
\text { DEPAN }\end{array}$ & .295 & .181 & .230 & 1.627 & .1 \\
\hline
\end{tabular}

Sumber : data primer yang diolah IBM SPSS Statistics Ver. 23

Tabel 7

Koefisien Determinasi

\begin{tabular}{|c|c|c|c|c|}
\hline $\begin{array}{c}\text { Mode } \\
\mathbf{l}\end{array}$ & $\mathbf{R}$ & $\mathbf{R}$ Square & Adjusted R Squre & $\begin{array}{c}\text { Std. Error of the } \\
\text { Estimete }\end{array}$ \\
\hline 1 &, $821^{a}$ &, 673 &, 593 & 1,42230 \\
\hline
\end{tabular}

Sumber : data primer yang diolah IBM SPSS Statistics Ver. 23

Tabel 8

Hasil Uji Simultan

\begin{tabular}{|l|c|c|c|c|c|}
\hline \multicolumn{1}{|c|}{ Model } & Sum of Sguares & Df & $\begin{array}{c}\text { Mean } \\
\text { Squares }\end{array}$ & F & Sig \\
\hline Regresen & 108,373 & 6 & 18,062 & 8,92 &, $000^{b}$ \\
Rasidual & 52,597 & 26 & 2,023 & 9 & \\
Total & 160,970 & 32 & & & \\
\hline
\end{tabular}

Sumber : data primer yang diolah IBM SPSS Statistics Ver. 23 
Berdasarkan hasil perhitunga menunjukan bahwa kondisi penilaian responden terhada variabel-variabel penelitian ini secara umum sudah baik. Hal ini dapat ditujukan dari banyaknya tanggapan kesetujuan yang tinggi dari responden terhadap kondisi dari masing-masing variabel penelitian. Dari hasil tersebut diperoleh bahwa enam variabel idependen yaitu Percaya Diri, Berorientasi Pada Tugas dan Hasil, Berani Mengambil Resiko, Kepemimpinan, Keorisinilan dan Berorientasi Pada Masa Depan memiliki pengaruh yang positif terhadap Keberhasilan Usaha Cafe di Kota Palembang baik secara Parsial maupun secara Simultan. Artinya Jiwa Kewirausahaan memiliki peran penting dalam Keberhasilan Usaha Cafe di kota Palembang

\section{Pengaruh Percaya Diri terhadap Keberhasilan Usaha}

Hasil uji t untuk variabel Percaya Diri $X_{1}$ diperoleh nilai $t_{\text {hitung }}=2,682$, dengan $t_{\text {table, }}$ 2,056. Dengan demikian berarti $t_{\text {hitung }}>t_{\text {table, }}$ yang berarti Ho ditolak da Ha diterima. Dengan demikian maka, hipotesis pertama dapat diterima. Arah koefisien regresi positif berarti bahwa Percaya Diri memiliki pengaruh yang positif dan signifikan terhadap keberhasilan usaha. Dengan kata lain dapat disimpulkan bahwa tingkat percaya diri yang baik seorang penggiat usaha akan mempercepat keberhasilan usaha Cafe dikota Palembang.

\section{Pengaruh Berorientasi Pada Tugas Dan Hasil Terhadaap Keberhasilan Usaha} Hasil uji t untuk variabel Berorientasi Pada Tugas dan Hasil $X_{2}$ diperoleh nilai $t_{\text {hitung }}$ $=0,530$ dengan $t_{\text {table, }}$ 2,056. Dengan demikian berarti $t_{\text {hitung }}<t_{\text {table, }}$ yang berarti Ho diterima dan Ha ditolak. Dengan demikian maka, hipotesis kedua tidak dapat diterima. Arah koefisien regresi Negatif berarti bahwa Berorientasi Pada Hasil memiliki pengaruh yang tidak positif signifikan terhadap Keberhasilan Usaha.

\section{Pengaruh Berani Mengambil Resiko Terhadap Keberhasilan Usaha \\ Hasil uji t untuk variabel Percaya Diri $X_{3}$ diperoleh nilai}

$t_{\text {hitung }}=-0,602$ dengan $t_{\text {table, }}, 2,056$.

Dengan demikian berarti $t_{\text {hitung }}<t_{\text {table, }}$ yang berarti Ho diterima da Ha ditolak. Dengan demikian maka, hipotesis ketiga tidak dapat diterima. Arah koefisien regresi negatif berarti bahwa Berani Mengambil Resiko memiliki pengaruh yang tidak positif signifikan dterhadap keberhasilan usaha.

\section{Pengaruh Kepemimpinan Terhadap Keberhasilan Usaha}

Hasil uji t untuk variabel Kepemimpinan $X_{4}$ diperoleh nilai $t_{\text {hitung }}=2,391$ dengan $t_{\text {table, }}$ 2,056. Dengan demikian berarti $t_{\text {hitung }}$ $>t_{\text {table, }}$ yang berarti Ho ditolak dan $\mathrm{Ha}$ diterima. Dengan demikian maka, hipotesis keempat dapat diterima. Arah koefisien regresi positif berarti bahwa Kepemimpinan memiliki pengaruh yang positif signifikan terhadap keberhasilan usaha.

\section{Pengaruh Keorisinilan Terhadap Keberhasilan Usaha}

Hasil uji t untuk variabel Keorisinilan $X_{5}$ diperoleh nilai

$t_{\text {hitung }}=1,105$ dengan $t_{\text {table, }}$ 2,056. Dengan demikian berarti $t_{\text {hitung }}<t_{\text {table, }}$ yang berarti Ho diterima dan Ha ditolak. Dengan 
demikian maka, hipotesis kelima tidak dapat diterima. Arah koefisien regresi Negatif berarti bahwa Keorisinilan memiliki pengaruh yang tidak positif signifikan terhadap keberhasilan usaha.

\section{Pengaruh Berorientasi Pada Masa Depan Terhadap Keberhasilan Usaha Hasil uji t untuk variabel Berorientas Pada Masa Depan $X_{6}$ diperoleh nilai $t_{\text {hitung }}$ $=1,627$ dengan $t_{\text {table, }}$ 2,056. Dengan demikian berarti $t_{\text {hitung }}<t_{\text {table, }}$ yang berarti Ho diterima dan Ha ditolak. Dengan demikian maka, hipotesis keenam tidak dapat diterima. Arah koefisien regresi Negatif berarti bahwa Berorientasi Pada Masa Depan memiliki pengaruh yang tidak positif signifikan terhadap keberhasilan usaha.}

\section{Pengaruh Jiwa Kewirausahaan (Percaya Diri, Berorientasi Pada Tugas Dan Hasil, Berani Mengambil Resiko, Kepemimpinan, Keorisinilan dan Berorientasi Pada Masa Depan) Terhadap Keberhasilan Usaha.}

Berdasarkan uji F pada tabel 4.19 diperoleh $F_{\text {hitung sebesar 8,929 dengan tingkat }}$ signifikan 0,000 dan nilai $F_{\text {table }}=2,42$. Jadi $F_{\text {hitung }}(8,929)>F_{\text {table }}(2,42)$, maka Ho ditolak dan $\mathrm{Ha}$ diterima. Nilai probabilitas $<0,05$ yaitu $(0,000<0,05)$, maka model regresi dapat digunakan untuk memprediksi variabel kepuasan konsumen (Y) atau dengan kata lain variabel Percaya diri $X_{1}$, Berorientasi Pada Tugas dan Hasil $X_{2}$, Berani mengambil resiko $X_{3}$, Kepemimpinan $X_{4}$, Keorisinilan $X_{5}$, dan Berorientasi Pada Masa Depan $X_{6}$ secara bersama-sama (simultan) berpengaruh positif dan signifikan terhadap Keberhasilan Usaha (Y).

\section{KESIMPULAN DAN SARAN}

\section{KESIMPULAN}

1. Berdasarkan pengolaan data dengan bantuan komputer program SPSS VERSI 23 yaitu 2 variabel $X_{1}$ Percaya Diri dan variabel $X_{4} \quad$ Kepemimpinan memiliki koefisien regredi yang positif dan signifikan secara parsial. Hal ini bisa di uji secara Simultan yaitu $F_{\text {hitung }}$ sebesar 8,929 dengan tingkat signifikan 0,000 dan nilai $F_{\text {table }}=2,42$. Jadi $F_{\text {hitung }}(8,929)$ $>F_{\text {table }}(2,42)$, maka Ho ditolak dan $\mathrm{Ha}$ diterima. Nilai probabilitas $<0,05$ yaitu $(0,000<0,05)$, maka model regresi dapat digunakan untuk memprediksi variabel kepuasan konsumen (Y) atau dengan kata lain variabel Percaya diri $X_{1}$, Berorientasi Pada Tugas dan Hasil $X_{2}$, Berani mengambil resiko $X_{3}$, Kepemimpinan $X_{4}$, Keorisinilan $X_{5}$, dan Berorientasi Pada Masa Depan $X_{6}$ secara bersama-sama berpengaruh nyata terhadap variabel keberhasilan usaha (Y). Namun di dalam melakukan uji secara Parsial (uji t) ada 4 variabel Jiwa Kewirausahaan yang tidak berpengaruh positif signifikan terhadap Keberhasilan Usaha yaitu variabel Berorientasi Pada Tugas dan Hasil $\left(X_{2}\right)$, Berani Mengambil Resiko $\left(X_{3}\right)$, keorisinilan $\left(X_{5}\right)$ dan Berorientasi Pada Masa Depan $\left(X_{6}\right)$.

2. Berdasarkan analisis secara Parsial ternyata hasil penelitian membuktikan bahwa variabel independen yaitu percaya diri $X_{1}$ mempunyai pengaruh yang positif dan signifikan terhadap Keberhasilan usaha dengan koefisien regresi sebesar 2,682 dengan tingkat signifikan sebesar 2,056 dengan taraf kepercayaan sebesar 0,05 .

3. Berdasarkan analisis secara Parsial ternyata hasil penelitian membuktikan bahwa variabel independen yaitu Kepemimpinan $X_{4}$ mempunyai pengaruh yang positif dan signifikan terhadap 
Keberhasilan usaha dengan koefisien regresi sebesar 2,391 dengan tingkat signifikan sebesar 2,056 dengan taraf kepercayaan sebesar 0,05.

4. Berdasarkan analisis secara Parsial ternyata hasil penelitian membuktikan bahwa variabel independen yaitu Beroroentasi Pada Tugas dan Hasil $X_{2}$ tidak mempunyai pengaruh positif signifikan terhadap Keberhasilan usaha dengan koefisien regresi sebesar 0,530 dengan tingkat signifikan sebesar 2,056 dengan taraf kepercayaan sebesar 0,05 .

5. Berdasarkan analisis secara Parsial ternyata hasil penelitian membuktikan bahwa variabel independen yaitu Berani Mengambil Resiko $X_{3}$ tidak mempunyai pengaruh positif signifikan terhadap Keberhasilan usaha dengan koefisien regresi sebesar -0,602 dengan tingkat signifikan sebesar 2,056 dengan taraf kepercayaan sebesar 0,05 .

6. Berdasarkan analisis secara Parsial ternyata hasil penelitian membuktikan bahwa variabel independen yaitu Keorisinilan $X_{5}$ tidak mempunyai pengaruh positif signifikan terhadap Keberhasilan usaha dengan koefisien regresi sebesar 1,105 dengan tingkat signifikan sebesar 2,056 dengan taraf kepercayaan sebesar 0,05 .

7. Berdasarkan analisis secara Parsial ternyata hasil penelitian membuktikan bahwa variabel independen yaitu Berorientasi Pada Masa Depan $X_{6}$ tidak mempunyai pengaruh positif signifikan terhadap Keberhasilan usaha dengan koefisien regresi sebesar 1,627 dengan tingkat signifikan sebesar 2,056 dengan taraf kepercayaan sebesar 0,05 .

8. Variabel yang paling dominan mempengaruhi Keberhasilan usaha adalah Variabel Percaya Diri $X_{1}$ dengan koefisien 2,682. Sedangkan variabel yang paling rendah mempengaruhi Keberhasilan Usaha adalah variabel Kepemimpinan $X_{4}$ dengan koefisien 2,391.

\section{SARAN}

Berdasarkan hasil penelitian dan pembahasan serta kesimpulan yang telah dikemukakan, maka penulis memberikan beberapa saran yang diharapkan dapat dijadikan masukan untuk para pengiat usaha Café di Kota Palembang sebagai berikut :

1. Melihat adanya pengaruh yang positif dan signifikan dari variabel jiwa kewirusahaan, perlu adanya usaha perbaikan yang mendalam oleh pengiat usaha Cafe terhadap variabel-Variabel jiwa kewirausahaan yang memiliki angka sig rendah yaitu Berorientasi Pada Tugas dan Hasil, Berani Mengambil Resiko, Keorisinilan, dan Berorientasi Pada Masa Depan.

2. Variabel yang memiliki koefisien paling rendah adalah Berani Mengambil Resiko. Diharapkan Pengiat usaha Cafe memperbaiki pemahamanya tentang Berani Mengambil Resiko karena, untuk mencapai kemajuan usaha harus berani keluar dari zona aman, harus berani menghadapi setiap ancaman yang datang baik dari faktor internal maupun dari faktor eksternal dan menjadikanya sebuah kesempatan atau peluang bisnis.

3. Sebaiknya variabel yang mempunyai pengaruh paling dominan terhadap keberhasilan usaha tetap memberikan pengaruh yang positif dan signifikan terhadap Keberhasilan Usaha Cafe.

4. Dari enam variabel Jiwa Kewirausahaan hanya ada dua variabel yang memiliki pengaruh positif signifikan terhadap keberhasilan usaha secara parsial dan 
empat variabel lainya tidak memiliki pengaruh positif signifikan terhadap keberhasilan usaha secara parsial. Peneliti menilai hal ini disebabkan oleh sebagian para pemilik usaha Cafe mempercayakan semua wewenang pada orang kepercayaan mereka sehingga setiap permasalahan dan pemecahanya dilakukan oleh orang lain. Sedangkan di dalam permasalahan tersebut bisa diambil sebuah pelajaran, karena memecahkan sebuh masalah memerlukan sebuah keterampilan khusus atau lebih tepatnya memerlukan sebuah Jiwa Kewirausahaan. Sebaiknya para pemilik usaha Cafe harus memiliki peran penting dalam kegiatan usahanya agar jiwa kewirausahaan dapat di miliki. Jadi pemilik usaha Cafe bukan hanya sekedar pemberi modal dan penerima laba tetapi pemilik usaha bisa dikatakan seorang wirausaha atau pengusaha sejati.

\section{DAFTAR PUSTAKA}

Alma Buchori. 2014. Kewirausaahaan.

Bandung : Alfabeta.

Artikel.2017. Pengertian Sempling: www. pengertian menurut para ahli. net (12maret2018).

BPS kota Palembang. 2018. Jumlah Restouran dan Rumah Makan kota Palembang 2017. Palembang: BPS kota Palembang.

Baqis, Farah. 2015 . Pengaruh jiwa kewirausahaan terhadap keberhasilan usaha distro di kota bandung (studi pada distro yang terdaftar pada kick di kota bandung). Bandung: Universitas Telkom Bandung.
Cindy, Rosmerio, Ricardo. 2016. Pengaruh jiwa kewirausahan dan kreativitas terhadap keberhasilan usaha pada sentra industri kripik pedas stiamanah Cimahi. Bandung: Universitas komputer Indonesia.

Intan YS 'dan'Seraneta K.2016. Menghubungkan para pelaku bisnis sektor Cafe. Jakarta : Majalah Sedap.

Kasmir.2014. Kewirausahaan. Jakarta : PT Raja grafindo Persada.

Kanal Informasi. 2018. Pengertian kafe: Https://www.kanal info.web.id.

Nurhasanah, Siti. 2016. Pratikum Statistik 2 untuk Ekonomi dan Bisnis. Jakarta:

Penerbit Salemba Empat.

Suryana. 2011. Kewirausahaan kiat dan proses menuju sukses. Jakarta: Salemba Empat.

Teguh Jiwa Brata. 2014. Desain unik senjata ampuh menjaring konsumen. Jakarta : Majalah Bisnis.

Tim Penyusun. 2016. Pedoman penulisan proposal dan \& skripsi cetakan keenam. Palembang: STIE Mulia Darma Pratama.

Wikipedia. 2017. Pengertian Cafe:https ://id.m.wikipedia-wiki_cafe (12 maret 2018). 